\title{
Cordelia's Dilemma, Historical Bias, and General Evolutionary Trends: Catfishes as a Case Study for General Discussions on Phylogeny and Macroevolution
}

\author{
Dilema de Cordelia, Sesgos Históricos y Tendencias Evolutivas Generales: Los Bagres Como un \\ Estudio de Caso Para Discusiones Generales en Filogénesis y Macroevolución \\ Rui Diogo
}

DIOGO, R. Cordelia's dilemma, historical bias, and general evolutionary trends: Catfishes as a case study for general discussions on phylogeny and macroevolution. Int. J. Morphol., 24(4):607-618, 2006.

SUMMARY: As noted Gould in his recent and last book «The structure of evolutionary theory», discourses on the high importance and frequency of evolutionary trends have consumed a great part of the research on the history of clades. Although aware that natural selection theoretically yields adaptation to immediate environments, many authors defend such trends as generalised improvements somehow conferring advantages across most or all experienced environments. The high importance given to evolutionary trends is questioned by Gould, who considers that such a high importance given to such evolutionary trends bears no necessary relationship to the relative frequency or casual weight of these events in evolution, but mainly to a major bias: trends tell histories, and evolution is a narrative history. In the present paper I briefly discuss this subject arguing that the case study provided by catfishes, a remarkably diverse group of Vertebrates reputed by its «general evolutionary trends», supports Gould's view according to which careful phylogenetic analysis of a clade often contradicts the supposed importance of general evolutionary trends in that clade's evolution.

KEY WORDS: Evolution; Morphology; Phylogeny; Siluriformes; Teleostei.

\section{INTRODUCTION}

As Gould noted in his last masterpiece 'The structure of evolutionary theory' (2002), discourses on the high importance and frequency of evolutionary trends have consumed a great part of the research on the history of clades. However, as stressed that author, the importance given to evolutionary trends - a psychological comment about our focus of attention - bears no necessary relationship to the relative frequency or casual weight of this phenomenon in the natural history of these clades. It seems more related to a main bias: trends tell stories, and evolution is a narrative science; Western tradition has always favoured directional tales of conquest and valour while experiencing great discomfort with the aimless undirected evolution (Gould, 2002). Thus, the high importance usually given to evolutionary trends could be more likely explained by a historical bias of nonreporting undirected evolution under the belief that this represents 'no interesting data' for evolution.

As noted Gould, such an historical bias is often seen, for example, in palaeontological publications, in which examples of stasis are often nonreported under the conviction that such stability represents "no data". These biases were compared by this author in his famous analogy with 'Cordelia's dilemma', in order to "memorialise the plight of King Lear's honest but rejected daughter". "When asked by Lear for a fulsome protestation of love in order to secure her inheritance, Cordelia, disgusted by the false and exaggerated speeches of her sisters Goneril and Regan, chose to say nothing, for she knew that 'my love's more ponderous than my tongue'; but Lear mistook her silence for hatred or indifference, and cut her off entirely (with tragic consequences later manifested in his own madness, blindness, and death), in proclaiming that 'nothing will come of nothing' " (Gould, 2002). Cordelia's dilemma, thus, arises in science when an important signal from nature is not seen or reported at all because scientists read the existing pattern as 'no data', literally as nothing at all. Therefore, "most clades, while waxing and waning in species diversity through time, show no outstanding overall directionality; but we do not know because the literature has never recognised, or 
attempted to tabulate, the frequency of such Ecclesiastical clades that change all the time, but 'go' nowhere in particular during their evolutionary peregrinations" (Gould).

According to Gould, there are two major, fundamental theoretical contradictions between the supposedly high frequency and fundamental importance of evolutionary trends in the history of natural clades and Darwin's theory. In the one hand, the more serious challenge of catastrophe and mass extinction raises the spectre of randomness and death for reasons unrelated to the adaptive struggles or normal times - the 'wheel of fortune versus the wedge or progressive trends' (Gould, 1989). In the other hand, a nondirectional vector of environmental change can only elicit a set of meandering responses in the adaptive adjustments of organisms (Gould, 2002).

\section{MATERIAL AND METHOD}

The biological group chosen as case study for this work is the teleost order Siluriformes, or catfishes, a group that is precisely reputed for its supposed 'general evolutionary trends' (Regan, 1911; Jayaram, 1966, 1968, 1971; Tilak, 1961, 1963ab, 1964, 1965, 1971; Alexander, 1965; Chardon, 1968; Gosline, 1975; Howes, 1983ab, 1985; Mo, 1991). The siluriforms, found in North, Central and South America, Africa, Europe, Asia and Australia, with fossils inclusively found in Antarctica, constitute a highly diversified, cosmopolitan group that, with more than 2700 species, represents about one third of all freshwater fishes and is one of the most morphologically and taxonomically diverse Vertebrate taxa (Burgess, 1989; Teugels, 2003; Diogo, 2004).

Therefore the study of the Siluriformes can provide useful data and illustrative examples for broader discussions on general phylogeny and macroevolution. With respect to this, it is particularly interesting to analyse whether or not the 'evolutionary trends' mentioned in catfish literature do really correspond, in a phylogenetic context, to general evolutionary trends. In the present paper I will examine some of the catfish 'general evolutionary trends' in the light of the phylogenetic results of a recent cladistic analysis of 440 morphological characters of the cephalic region and pectoral girdle of 87 genera representing all 32 extant catfish families (Diogo, 2004). These 'evolutionary trends' are: 1) the strong ankylosis between a posterodorsomesial 'transcapular' process of the posttemporo-supracleithrum and the anterior vertebrae; 2) the loss of the posterior cartilage of the autopalatine; 3 ) the loss of the sesamoid bone 1 of the suspensorium; 4) the loss of the ascending portion of Meckel's cartilage; 5) the strong ankylosis between the mesial limb of the posttemporo-supracleithrum and the neurocranium; and 6) the differentiation of the extensor tentaculi in different bundles (Regan; Jayaram, 1966, 1968, 1971; Tilak, 1961, 1963ab, 1964, 1965, 1971; Alexander; Chardon; Gosline, 1975; Howes, 1983ab, 1985).

A detailed description of the morphological features mentioned in this paper is given in papers as e.g. Alexander; Chardon; Gosline (1975); Howes (1983ab, 1985), as well as in the several works on catfish comparative anatomy recently published by the author (Diogo, 2004; Diogo \& Chardon, 2000, 2003; Diogo \& Vandewalle, 2003; Diogo et al., 2000ab, 2001).

\section{RESULTS AND DISCUSSION}

The authors defending the existence of the catfish 'evolutionary trends' listed above, as well as those defending the existence of evolutionary trends in general, are aware that natural selection theoretically only yields adaptation to immediate environments. They thus are aware that this is an idea clearly not conducive to sustained general directional trends through geological time given the effectively random environmental changes through substantial geological intervals (Gould, 2002). However, these authors often defend that such trends refer to "generalised biomechanical improvements somehow conferring advantages across most or all experienced environments" (Gould, 2002). In order to analyse whether or not this is the case within the six catfish 'general evolutionary trends' listed above, these will be discussed below in face of the phylogenetic results obtained in the recent cladistic analysis on catfish higher-level phylogeny of Diogo (2004).

With respect to the strong ankylosis between a posterodorsomesial transcapular process of the posttemporo-supracleithrum and the anterior vertebrae (Chardon), in view of the author's phylogenetic results this feature only evolved twice within the Siluriformes: in the scoloplacids and in the clade constituted by the chacids + clariids + plotosids + amblycipitids + akysids + sisorids + erethistids + aspredinids, where it is secondarily lost by plotosids, amblycipitids and sisorids as e.g. Glyptosternon (Fig. 1). Therefore, this feature seems far from constituting a classic 'general evolutionary trend' evolving independently several times by providing 'generalised biomechanical improvements' and conferring 'advantages across most or all experienced environments' inhabited. 


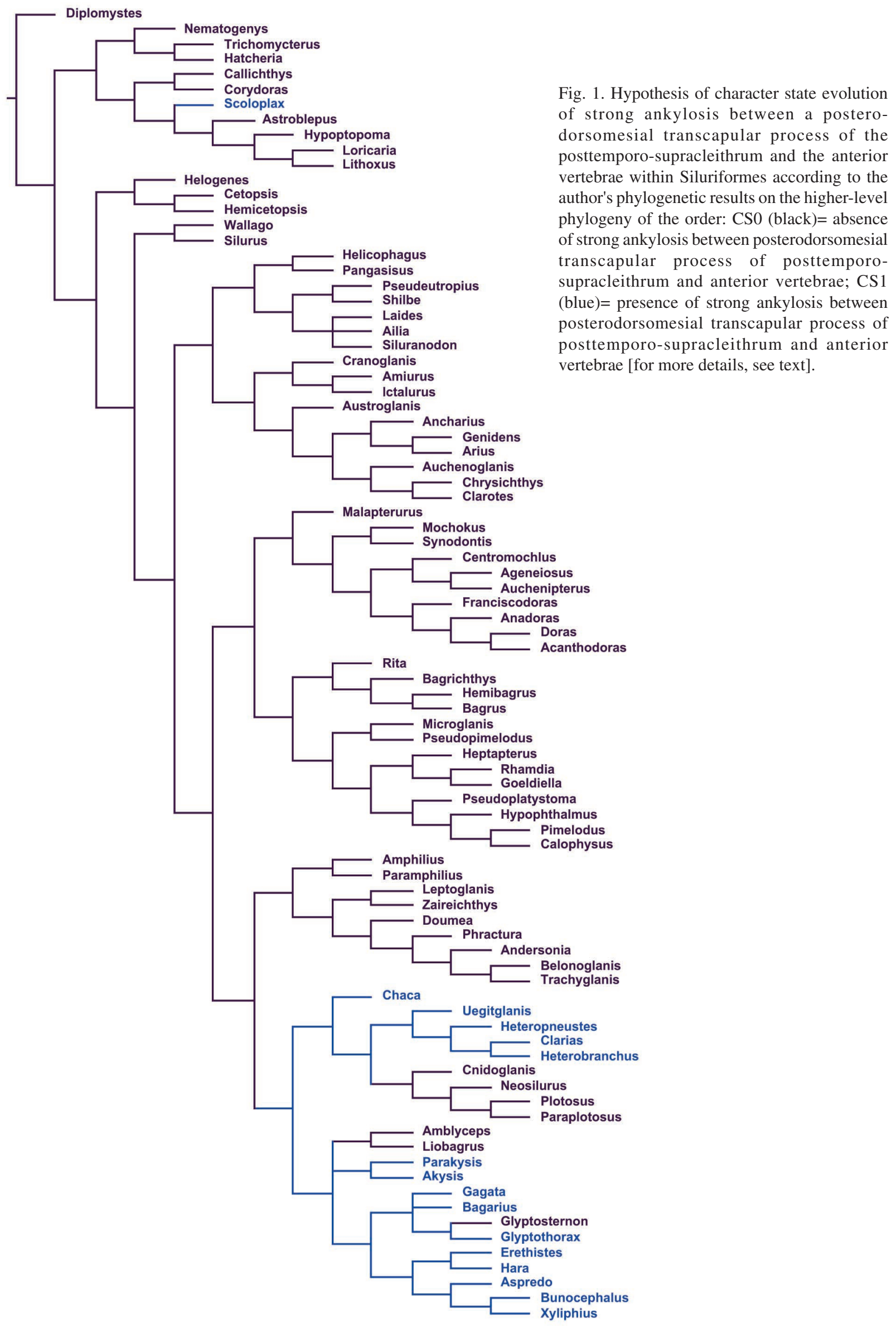


A similar case also applies to the loss of the posterior cartilage of the autopalatine (Diogo et al., 2000ab, 2001). As illustrated in Fig. 2, this feature seemingly only occurred two or eventually three times on catfish evolutionary history, being only found in a rather reduced number of catfish families: amphiliids, trichomycterids, callicthyids, scoloplacids, loricariids and astroblepids (Fig. 2).

Regarding the loss of the sesamoid bone 1 of the suspensorium (Diogo et al., 2001; Diogo \& Chardon, 2003), this apparently occurred three or four times within catfish evolutionary history (Fig. 3). However, two of the homoplasic losses of this bone have occurred in relatively small catfish clades: in mochokids and in the bagrid genus Rita. Therefore, the sesamoid bone 1 of the suspensorium is present in the great majority of the catfish families (Fig. 3). The loss of this bone thus hardly seems to constitute a classic example of unequivocal, typical 'general generalised trend' within the order Siluriformes.

The ascending portion of Meckel's cartilage (Mo; Diogo et al., 2000b) was apparently independently lost five times: in the combined clade of callicthyids + scoloplacids + loricariids + astroblepids, in the silurids, in the mochokids, in the amphiliids, and in the clariids (Fig. 4). This feature seems to be strongly correlated with a markedly benthic type of life, as exhibited by callichthyids, scoloplacids, loricariids, astroblepids, mochokids, amphiliids and clariids (Burgess), rather than a catfish 'general evolutionary trend' referring to a 'generalised biomechanical improvement conferring advantages across most or all experienced environments' (see above). This strong correlation is probably explained by the fact that these markedly benthic catfishes have a particularly depressed head to provide further stability against the substratum, and, consequently, a particularly depressed mandible (Alexander). In fact, the only not markedly benthic catfishes in which the ascending portion of Meckel's cartilage is also absent are the silurids. Therefore, the loss of the ascending portion of Meckel's cartilage seems, again, somewhat far from constituting a classic example of 'general evolutionary trend' providing 'unequivocal advantages across most or all experienced environments' inhabited by the fishes of this order.

The strong ankylosis between the mesial limb of the posttemporo-supracleithrum and the neurocranium (Alexander; Chardon) does also not seem to represent an example of classic 'general evolutionary trend'. In fact, this feature apparently developed independently in six small and restricted catfish groups (Fig. 5). Moreover, it is difficult to talk about a 'general evolutionary tendency' towards a strong, firm suture between the mesial limb of the posttemporosupracleithrum and the neurocranium, when this mesial limb of the posttemporo-supracleithrum simply became completely undifferentiated in several taxa commonly considered as morphologically 'specialised' catfish groups (e.g. scoloplacids, astroblepids, loricariids, sisorid glyptosternoids and clariids; see e.g. Alexander; Chardon; Mo; de Pinna, 1993; Diogo, 2003, 2004).

With respect to the differentiation of the extensor tentaculi in different bundles (Diogo et al., 2000b; Diogo \& Vandewalle), this feature occurred at least in four different occasions: in the clade callicthyids + scoloplacids + astroblepids + loricariids; in the silurids; in the claroteid genus Auchenoglanis; and in the clade malapterurids + doradids + auchenipterids + mochokids + bagrids + pimelodids + amphiliids + chacids + plotosids + clariids + amblycipitids + akysids + sisorids + erethistids + aspredinids, where it is secondarily lost within chacids and clariids (Fig. $6)$. It thus seems that, contrarily to the features discussed above, the differentiation of the extensor tentaculi in different bundles could, in theory, provide an example of a true catfish 'general evolutionary trend'.

As said above, the loss of the ascending portion of Meckel's cartilage could be strongly correlated with the marked depression of the head in markedly benthic fishes. Thus, the loss of this ascending portion of Meckel's cartilage does not confer, at least in theory, a major theoretical advantage to nonmarkedly benthic catfishes presenting a well-developed, high coronoid process. In reality, among the numerous nonmarkedly benthic catfishes only the silurids lack the ascending portion of Meckel's cartilage (note: in silurids the coronoid process is only moderately developed, being clearly less developed than in catfishes such as claroteids, nematogenyids or cetopsids). This is also the case of the firm ankylosis between the mesial limb of the posttemporo-supracleithrum and the neurocranium, which does not seem to be particularly advantageous to catfishes presenting some "flexibility in the head" (Chardon; Gosline, 1977).

However, the subdivision of the extensor tentaculi in different bundles allows a wider range of movements to the catfish palatine-maxillary system, and, consequently, to the characteristic maxillary barbels of these fishes (Alexander; Gosline, 1975; Diogo et al., 2000b). Thus it is not unreasonable to think that, within an order in which the palatine-maxillary system is invariably present, the subdivision of the extensor tentaculi could effectively somehow constitute a 'generalised biomechanical improvement' across several different environments. In fact, contrarily to the loss of the ascending portion of Meckel's cartilage and to the strong ankylosis between the mesial limb of the posttemporo-supracleithrum and the neurocranium, this subdivision of the extensor tentaculi is not, at least apparently, strongly correlated with a certain particular lifestyle or with a small, restricted catfish group, being, in fact, present in most siluriforms (Fig. 6). 


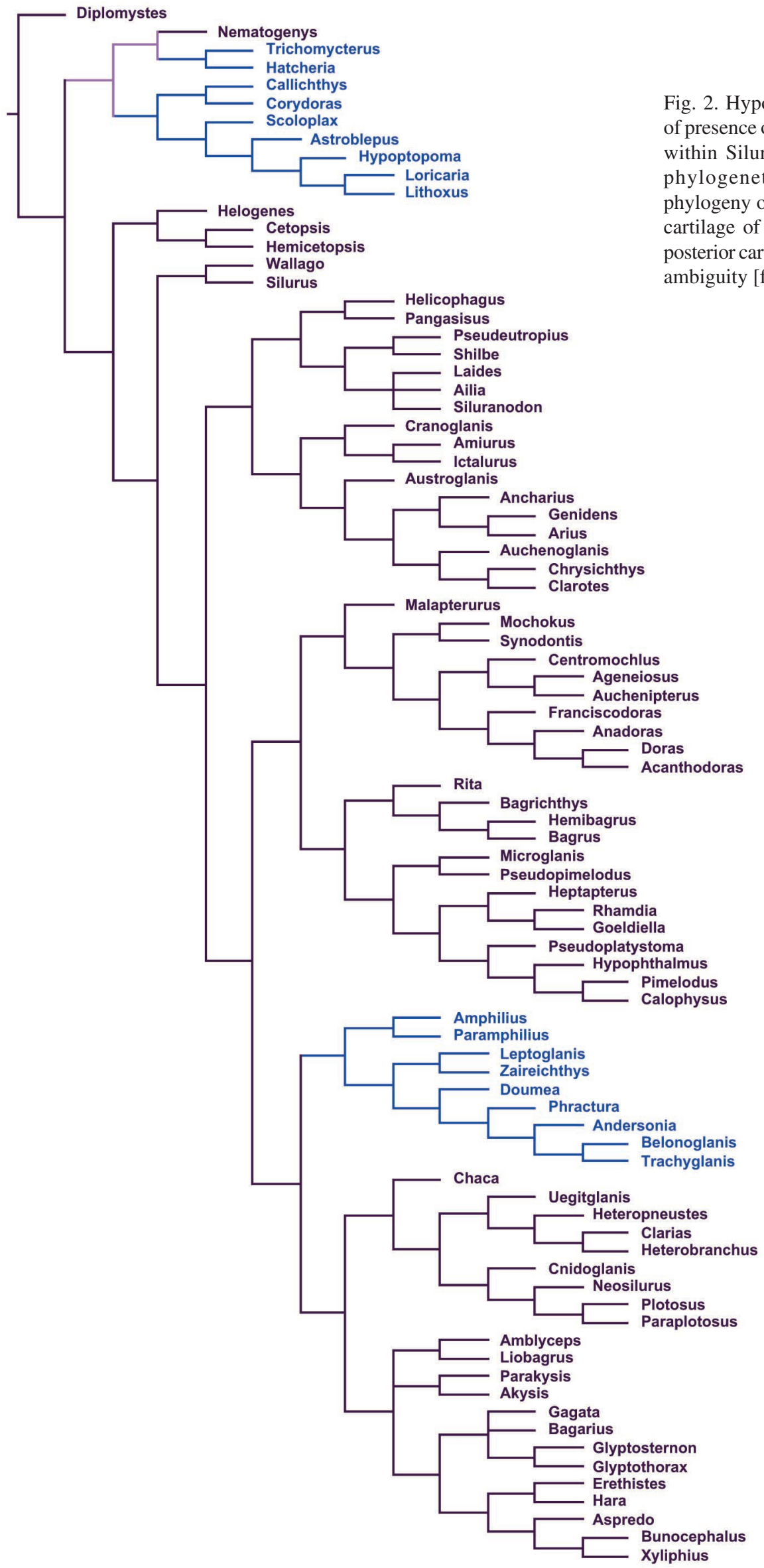




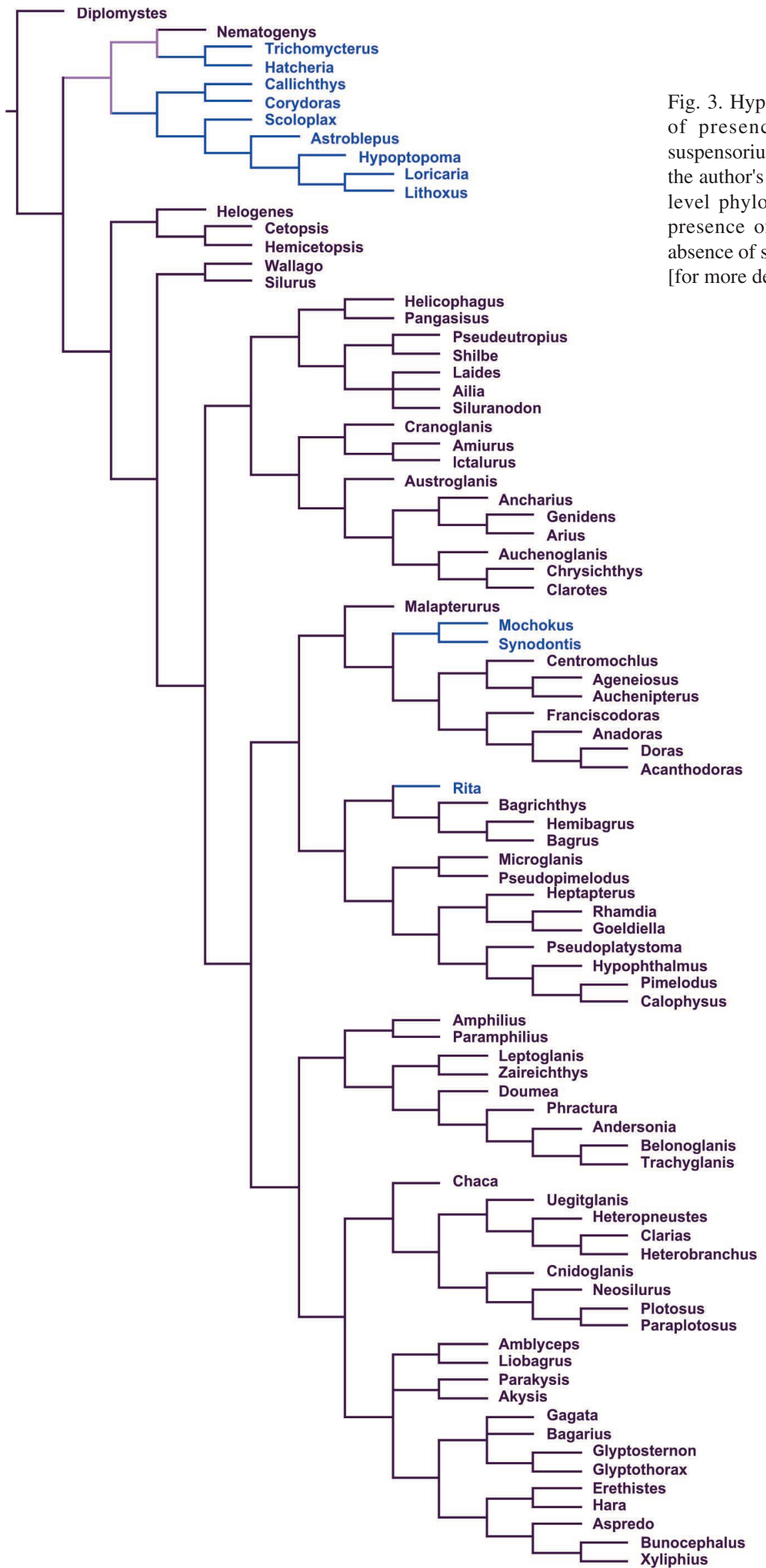




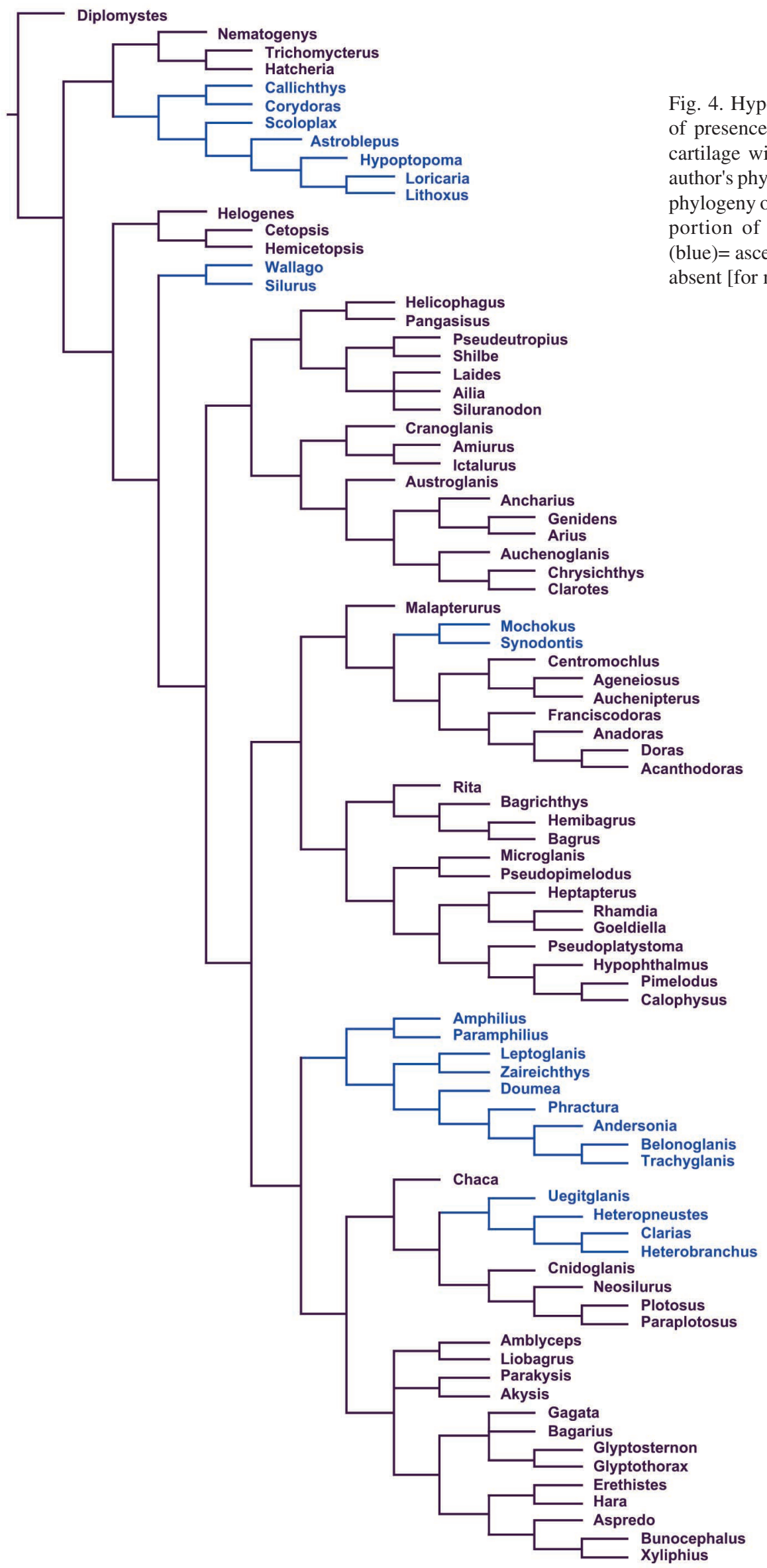




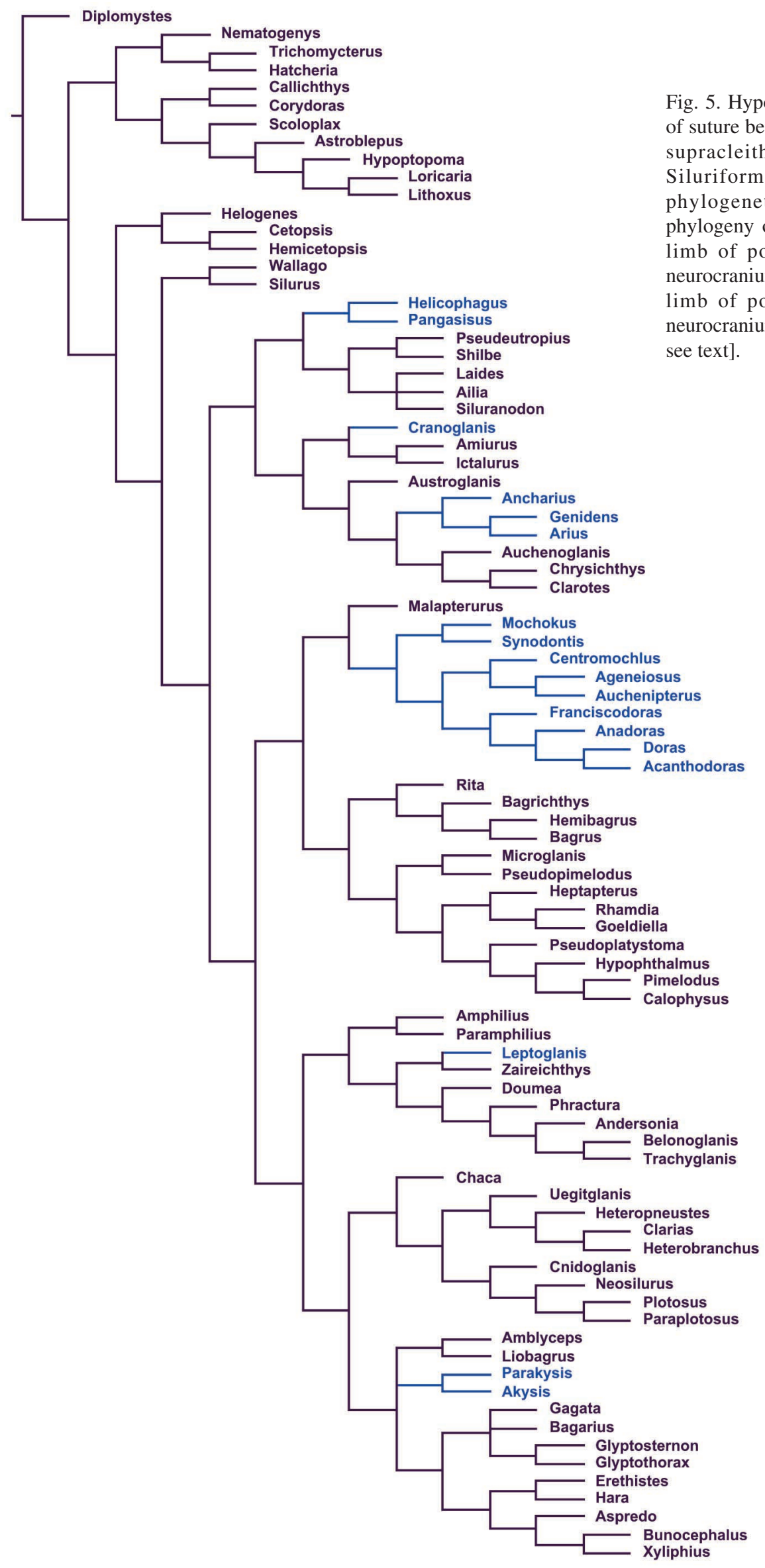




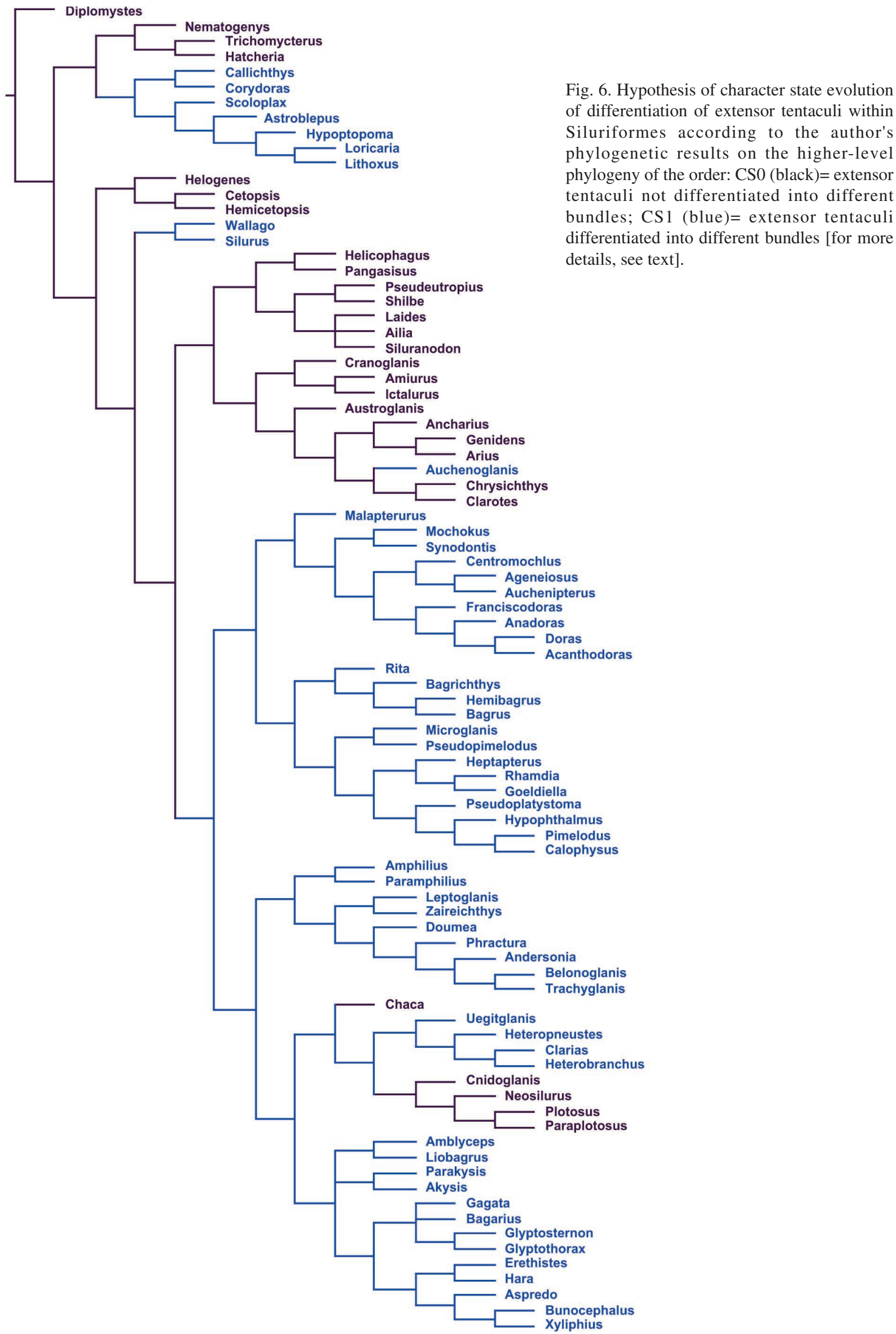

615 


\section{GENERAL COMMENTS}

Among the six characters discussed above supposedly constituting 'general evolutionary trends' within the Siluriformes, only the subdivision of the extensor tentaculi in different bundles seems to constitute a potential example of classical 'general evolutionary trend'. Therefore, the present work supports the view that the importance usually attributed to 'general evolutionary trends' is likely often overvalued as the result of an historical bias leading us to invariably consider the 'non-trends' as 'non-interesting' data and to stoutly try to provide examples of supposed 'general trends'. This case-study thus seems to support Gould's premonitory words mentioned above: "I suspect that most clades, while waxing and waning in species diversity through time, show no outstanding overall directionality, but we do not know because the literature has never recognised, or attempted to tabulate, the frequency of such Ecclesiastical clades that change all the time, but 'go' nowhere in particular during their evolutionary peregrinations".
ACKNOWLEDGEMENTS: I thank J. Cambray (Albany Museum of Grahamstown), G.G. Teugels (Musée Royal de l'Afrique Centrale), P. Laleyé (Université Nationale du Bénin), R. Vari, J. Williams and S. Jewett (National Museum of Natural History) and P. Duhamel (Muséum National D'Histoire Naturelle) for kindly providing a large part of the biological material used in my studies of catfishes. I would also like to acknowledge I. Doadrio, I. Peng, G.G. Teugels, R.P. Vari, S. Weitzman, T. Abreu, A. Zanata, B.G. Kapoor, F. Meunier, S. He, D. Adriaens, F. Wagemans, C. Oliveira, E. Parmentier, and specially M.M. de Pinna, P. Skelton, M.J.L. Stiassny, F.J. Poyato-Ariza, G. Arratia, T. Grande, M.G., H. Gebhardt, M. Ebach, A. Wyss, J. Waters, B. PerezMoreno, G. Cuny, A. Choudhury, M. Vences, S.H. Weitzman, L. Cavin, F. Santini, J.C. Briggs, L.M. Gahagan, Philiphe J.G. Maisey, M. Gayet, J. Alves-Gomes, G. Lecointre and L. Taverne, and particularly E. Parmentier, P. Vandewalle and M. Chardon for their helpful discussions, their criticism, their advice and their assistance. I am particularly thankful to two anonymous reviewers for their helpful comments on a previous version of this paper.

DIOGO, R. Dilema de cordelia, sesgos históricos y tendencias evolutivas generales: los bagres como un estudio de caso para discusión general en filogénesis y macroevolución. Int. J. Morphol., 24(4):607-618, 2006.

RESUMEN: Como señala Gould en su reciente y último libro «La estructura de la teoría evolutiva», las discusiones sobre la gran importancia y frecuencia de tendencias evolutivas han consumido una gran parte de la investigación sobre la historia de clados. Aún conociendo que la selección natural, teóricamente, se adapta a un ambiente específico, muchos autores defienden tales tendencias como mejoras generalizadas, las cuales de alguna manera confieren ventajas a través de la mayoría o de todas las experiencias medioambientales. La gran importancia dadas a las tendencias evolutivas es cuestionada por Gould, quien considera que esta gran importancia es debida a un sesgo histórico: tendencias cuentan historias y, la evolución es una historia narrativa. En el presente trabajo comento brevemente este tema argumentando que el estudio realizado en bagres, un grupo de Vertebrados notablemente diverso, contradice la supuesta gran importancia de las tendencias evolutivas generales en la evolución de clados.

PALABRAS CLAVE: Evolución; Morfología; Filogénesis; Bagres; Teleósteos

\section{REFERENCES}

Alexander, R. M. Structure and function in catfish. J. Zool. (Lond.), 148:88-152, 1965.

Burgess, W. E. An atlas of freshwater and marine catfishes: a preliminary survey of the Siluriformes. Berkshire, TFH Publications, 1989.

Chardon, M. Anatomie comparée de l'appareil de Weber et des structures connexes chez les Siluriformes. Ann. Mus. R. Afr. Centr., 169:1-273, 1968.

De Pinna, M.C.C. Higher-level phylogeny of Siluriformes, with a new classification of the order (Teleostei,
Ostariophysi). Unpublished $\mathrm{PhD}$ thesis, City University of New York, 1993.

Diogo, R. Higher-level phylogeny of Siluriformes: an overview. In G Arratia, BG Kapoor, M Chardon, R Diogo, eds. Catfishes. Enfield, Science Publishers, pp. 353-84, 2003.

Diogo, R. Morphological evolution, aptations, homoplasies, constraints, and evolutionary trends: catfishes as a case study on general phylogeny and macroevolution. Enfield, Science Publishers, 2004. 
Diogo, R. \& Chardon, M. Homologies Between Different Adductor Mandibulae Sections of Teleostean Fishes, with a Special Regard to Catfishes (Teleostei: Siluriformes). J. Morphol., 243:193-208, 2000.

Diogo, R. \& Chardon, M. Homologies and evolutionary transformation of the skeletal elements of catfish (Teleostei: Siluriformes) suspensorium: a morphofunctional hypothesis. In AL Val, BG Kapoor, eds. Fish adaptations. Enfield, Science Publishers, pp. 275 84, 2003.

Diogo, R. \& Vandewalle, P. Review of superficial cranial musculature of catfishes, with comments on plesiomorphic states. In G Arratia, BG Kapoor, M Chardon, R Diogo, eds. Catfishes. Enfield, Science Publishers, 2003. pp. 47-69.

Diogo, R; Oliveira, C. \& Chardon, M. On the anatomy and function of the cephalic structures in Phractura (Siluriformes: Amphiliidae), with comments on some striking homoplasies occurring between the doumeins and some loricarioid catfishes. Belg. J. Zool., 130:117-130, 2000a.

Diogo, R; Oliveira, C. \& Chardon, M. The origin and transformation of catfish palatine-maxillary system: an example of adaptive macroevolution. Neth. J. Zool., 50:373-88, 2000b.

Diogo, R; Oliveira, C. \& Chardon, M. On the homologies of the skeletal components of catfish (Teleostei: Siluriformes) suspensorium. Belg. J. Zool., 131:155-71, 2001.

Gould, S. J. The wheel of fortune and the wedge of progress. Nat. Hist. 98:14-21, 1989.

Gould, S. J. The structure of evolutionary theory. Harvard, Harvard University Press, 2002.

Gosline, W. A. The palatine-maxillary mechanism in catfishes with comments on the evolution and zoogeography of modern siluroids. Occ. Pap. Calif. Acad. Sci., 120:1-31, 1975.

Gosline, W. A. The structure and function of the dermal pectoral girdle in bony fishes with particular reference to ostariophysines. J. Zool. (Lond.), 183:329-38, 1977.

Howes, G. J. Problems in catfish anatomy and phylogeny exemplified by the Neotropical Hypophthalmidae (Teleostei Siluroidei). Bull. Br. Mus. Nat. Hist. (Zool.), 45:1-39, 1983a.
Howes, G.J. The cranial muscles of the loricarioid catfishes, their homologies and value as taxonomic characters. Bull. Br. Mus. Nat. Hist. (Zool.), 45:309-45, 1983b.

Howes, G.J. The phylogenetic relationships of the electric family Malapteruridae (Teleostei: Siluroidei). J. Nat. Hist., 19:37-67, 1985.

Jayaram, K.C. Contribution to the study of fishes of the family Bagridae, I - a systematic account of the African genera with a new classification of the family. Bull. Inst. Fond. Afrique Noire, 28:1064-139, 1966.

Jayaram, K.C. Contributions to study of the bagrid fishes (Siluroidea: Bagridae), 3 - a systematic account of the Japanese, Chinese, Malayan and Indonesian genera. Treubia Mus. Zool. Bogoriense, 27:287-386, 1968.

Jayaram, K.C. Contributions to study of the bagrid fishes, 6 - the skeleton of Rita gogra (Sykes). J. Zool. Soc. India, 22:117-45, 1971.

Mo, T. Anatomy, relationships and systematics of the Bagridae (Teleostei: Siluroidei) with a hypothesis of siluroid phylogeny. Theses Zoologicae, 17:1-216, 1991.

Regan, C.T. The classification of the teleostean fishes of the order Ostariophysi - 2 Siluroidea. Ann. Mag. Nat. Hist., 8:553-77, 1911

Teugels, G.G. State of the art of recent siluriform systematics. In G Arratia, BG Kapoor, M Chardon, R Diogo, eds. Catfishes. Enfield, Science Publishers, pp. 317-52, 2003.

Tilak, R. The osteocranium and the Weberian apparatus of Eutropiichthys vacha (Ham.) and Eutropiichthys murius (Ham.): a study of inter-relationships. Zool. Anz., 167:413-30, 1961.

Tilak, R. The osteocranium and the Weberian apparatus of the fishes of the family Sisoridae (Siluroidea): a study in adaptation and taxonomy. Zeitsch. Wissensch. Zool., 169:281-320, 1963a.

Tilak, R. Studies on the nematognathine pectoral girdle in relation to taxonomy. Ann. Mag. Nat. Hist., 13:145$55,1963 b$.

Tilak, R. The osteocranium and Weberian apparatus of the family Schilbeidae. Proc. Zool. Soc. Lond., 143:1-36, 1964. 
Tilak, R. The comparative morphology of the osteocranium and the Weberian apparatus of Tachysuridae (Pisces: Siluroidei). J. Zool. (Lond.), 146:150-74, 1965.

Tilak, R. A study of the osteocranium, the Weberian apparatus and the girdles of Chaca chaca (Hamilton): Family Chacidae, Siluroidei. Zool. Anz., 186:417-35, 1971.
Correspondence to:

Dr. Rui Diogo

Department of Anthropology,

The George Wasfington University,

2110 G St. $\mathcal{N W}$

Wasfington, $\mathcal{D C} 20052$

USA

Email:R.Diogo@ulg.ac.be

Received: 06-04-2006

Accepted: 03-08-2006 